\title{
Pengembangan paket ipa terpadu berbasis inkuiri dengan tema cahaya sebagai peluang untuk meningkatkan pemahaman konsep siswa SMP kelas VIII semester II
}

\author{
Riski Lutfiani, Supriyono Koes H.*, Metri Dian Insani \\ Universitas Negeri Malang, Jl. Semarang No. 5 Malang, Jawa Timur, Indonesia \\ *Penulis korespondensi, Surel: supriyono.koeshandayanto.fmipa@um.ac.id
}

Paper received: 01-03-2021; revised: 15-03-2021; accepted: 31-03-2021

\begin{abstract}
The purpose of this research was to produce an intregated science package contained light theme based on inquiry as an opportunity to improve conceptual comprehension. The research used Borg and Gall's developing model. The result of this research is integrated science package were include of student handbook and teacher guidance book. The feasibility test result were 4,35 of mean score for student handbook, validation test of teacher handbook was 4,26 and small group test result was 4,32 of mean score. Based on the assessment, the developed learning package could improve the conceptual comprehension. This research require to test-drive furthermore because this development research only small group test.
\end{abstract}

Keywords: integrated science package; inquiry; conceptual comprehension; light

\begin{abstract}
Abstrak
Tujuan penelitian ini untuk menghasilkan produk paket IPA terpadu berbasis inkuiri pada tema cahaya sebagai peluang untuk meningkatkan pemahaman konsep siswa. Penelitian ini menggunakan model pengembangan ADDIE (2009). Hasil dari penelitian ini adalah paket IPA terpadu berupa buku pegangan siswa dan buku panduan guru. Hasil validasi menunjukkan bahwa nilai rata-rata yang diperoleh buku pegangan siswa sebesar 4.35 dengan kriteria sangat valid, nilai rata-rata buku panduan guru sebesar 4.26 dengan kriteria sangat valid, dan hasi uji coba kelompok kecil memperoleh nilai rata-rata sebesar 4.32 dengan kriteria sangat valid. Berdasarkan penilaian tersebut, paket yang telah dikembangkan diprediksi mampu meningkatkan pemahaman konsep siswa. Penelitian ini perlu diuji coba lebih lanjut karena pada penelitian pengembangan ini hanya sampai uji coba kelompok kecil.
\end{abstract}

Kata kunci: paket IPA terpadu; inkuiri; pemahaman konsep; cahaya

\section{Pendahuluan}

Ilmu Pengetahuan Alam merupakan ilmu yang mempelajari makhluk hidup, lingkungan, dan interaksi yang menuntut pemahaman dan keaktifan siswa. Keaktifan siswa secara langsung dapat memberikan pengetahuan yang mendalam tentang materi yang dipelajari dan dapat memahami fenomena nyata yang hubungannya sangat erat dalam kehidupan siswa sehari-hari. Hal ini sesuai dengan pendapat Kusumawardhany (2012) dan Aisya (2014) bahwa pembelajaran IPA pada kurikulum 2013 di sekolah menengah diharapkan menjadi wahana bagi siswa untuk mempelajari diri sendiri, alam sekitar, dan penerapannya di dalam kehidupan sehari-hari.

Bedasarkan hasil wawancara yang dilakukan di salah satu SMP di kabupaten Malang diketahui bahwa pembelajaran IPA yang berlangsung masih belum menerapkan pembelajaran secara terpadu. Salah satu contohnya pada materi kelas VIII semester II yaitu tentang cahaya, pembelajaran masih dilakukan secara terpisah-pisah antar bidang biologi, fisika, dan kimia. Materi cahaya diajarkan pada dua bidang ilmu yang berbeda yaitu bidang fisika dan biologi. Materi tersebut juga diajarkan oleh dua guru yang berbeda pula. 
Berdasarkan hasil wawancara yang dilakukan kepada dua orang guru IPA pada sekolah tersebut juga diketahui bahwa selama proses pembelajaran, guru IPA menggunakan bahan ajar yang berbeda. Bahan ajar yang digunakan yaitu buku LKS handout yang disusun oleh guru sendiri. Buku LKS berisi ringkasan materi yang dilengkapi dengan soal pilihan ganda, uraian singkat, dan soal uraian yang meminta siswa menjelaskan jawaban secara lengkap. Handout berisi rangkuman materi esensial yang harus disampaikan ketika pembelajaran berlangsung.

Materi cahaya pada kurikulum 2013 yang berlaku saat ini disajikan dalam KD 3.11, akan tetapi materi yang disajikan masih belum memadukan seluruh bidang kajian IPA. Berdasarkan analisis KD yang telah dilakukan, materi cahaya ini dapat dipadukan dengan KDKD yang terkait sehingga materi tersebut dapat disajikan secara terpadu. KD-KD yang terkait dengan materi cahaya yaitu KD 3.1, KD 3.2, KD 3.4, dan KD 3.6. Masing-masing KD tersebut diajarkan pada jenjang kelas yang berbeda. KD 3.1 dan KD 3.2 diajarkan pada kelas VIII semester I, KD 3.4 diajarkan pada kelas IX semester I, KD 3.6 diajarkan pada kelas VII semester II, dan KD 3.11 diajarkan pada kelas VIII semester II.

Berdasarkan hasil wawancara dengan dua guru IPA tersebut mendapatkan hasil bahwa pada materi cahaya dapat diajarkan secara terpadu, akan tetapi guru masih belum sanggup meyusun bahan ajar yang bersifat terpadu pada materi tersebut. Bahan ajar yang selama ini digunakan oleh guru juga minim akan kegiatan percobaan di laboratorium, siswa hanya memperoleh konsep melalui penjelasan guru. Kurikulum yang berlaku saat ini menuntut pembelajaran yang melibatkan keaktifan siswa. Salah satu cara untuk melibatkan siswa aktif dalam proses pembelajaran yaitu dengan dilakukannya kegiatan penyelidikan ilmiah, sehingga peneliti tertarik untuk mengembangkan bahan ajar yang dapat melibatkan siswa secara aktif melalui kegiatan penyelidikan ilmiah.

Penelitian oleh Koes H (2010) menunjukkan bahwa guru IPA SMP di Malang Raya membutuhkan paket IPA terpadu dan panduan penggunaannya untuk menumbuhkan kompetensi siswa. Paket pembelajaran adalah sebuah paket atau seperangkat buku yang terdiri dari bahan ajar materi tertentu yang dilengkapi dengan soal tes atau evaluasi. Minimnya ketersediaan bahan ajar IPA terpadu, maka peneliti mengembangkan bahan ajar berupa paket pembelajaran IPA terpadu dengan mengambil tema cahaya.

Pengembangan paket IPA terpadu yang telah ada saat ini yaitu paket IPA terpadu berbasis konstruktivisme berdasarkan kurikulum KTSP yang dikembangkan oleh Bachtiar (2010). Pembelajaran saat ini mengacu pada kurikulum 2013, sehingga pengembangan paket IPA terpadu berdasarkan kurikulum 2013 perlu dilakukan untuk menunjang pembelajaran. Pada implementasinya, pengembangan paket IPA terpadu perlu memperhatikan pendekatan pembelajaran yang tepat, agar pembelajaran dengan menggunakan paket tersebut dapat bermakna bagi siswa.

Prinsip pembelajaran IPA berdasarkan kurikulum 2013 disarankan dengan menggunakan pembelajaran berbasis discovery/inkuiri (Permendikbud No. 65 Tahun 2013). Langkah-langkah inkuiri yang digunakan sangat bermanfaat bagi siswa untuk mengembangkan proses berpikirnya dalam memecahkan masalah (Poerwati \& Amri, 2013). Pemahaman yang diperoleh siswa melalui langkah-langkah inkuiri tersebut akan menjadi pembelajaran bermakna serta hasil belajar yang diperoleh dapat mencapai tiga ranah yaitu sikap, pengetahuan, dan keterampilan yang sesuai dengan kurikulum 2013 (Balim, 2009). 
Inkuiri juga terbukti mampu melatih siswa untuk berpikir tingkat tinggi, metakognisi, dan keterampilan proses sains (Prayitno, 2012).

Sebagai penunjang dalam kegiatan pembelajaran berbasis inkuiri maka diperlukan bahan ajar yang menuntut siswa menemukan konsep melalui metode ilmiah. Namun bahan ajar yang ada saat ini kurang dapat mempresentasikan aspek metode ilmiah. Pembelajaran saat ini masih cukup banyak mengacu pada teacher centered sehingga kurang adanya upaya untuk melibatkan siswa dalam menemukan konsep sendiri.

Pemahaman konsep merupakan kemampuan untuk menerapkan pengetahuan intregatif ke situasi kehidupan nyata sehari-hari (Koes H, 2006). Kurniawan (2013) menyatakan bahwa untuk mencapai tujuan pembelajaran yang maksimal, maka siswa harus memahami konsep-konsep yang dipelajari. Anggraeni (2013) juga menyebutkan bahwa saat ini siswa kurang diberikan kesempatan untuk menggali pengetahuan dan mengaitkan konsep yang dipelajari ke suatu kondisi lingkungan yang berbeda sehingga konsep yang diajarkan kurang bermakna bagi siswa, hanya bersifat hafalan yang berdampak pada rendahnya pemahaman konsep siswa. Hasil penelitian tersebut menjadi alasan peneliti untuk mengembangkat paket IPA terpadu berbasis inkuiri untuk meningkatkan pemahaman konsep siswa.

Berdasarkan uraian di atas, maka peneliti berupaya untuk mengembangkan suatu bahan ajar berupa paket pembelajaran IPA terpadu berbasis inkuiri. Pengembangan bahan ajar ini dilakukan untuk mata pelajaran IPA pada tema cahaya yang diajarkan kepada siswa SMP kelas VIII semester II. Dengan demikian penelitian pengembangan yang dilaksanakan oleh peneliti berjudul "Pengembangan Paket IPA Terpadu Berbasis Inkuiri dengan Tema Cahaya Sebagai Peluang untuk Meningkatkan Pemahaman Konsep Siswa SMP Kelas VIII Semester II".

\section{Metode}

Penelitian ini merupakan penelitian pengembangan dengan menggunakan model pengembangan ADDIE (2009). Tahapan dari model pengembangan ADDIE yang diterapkan dalam penelitian ini yaitu: (1) Analysis, (2) Design, (3) Development, (4) Implementation, dan (5) Evaluations. Data yang diperoleh berupa data kualitatif dan kuantitatif. Data kualitatif berupa komentar dan saran dari validator terhadap paket yang dikembangkan sedangkan data kuantitatif berupa skor 5, 4, 3, 2, 1 yang diperoleh dari hasil penilaian validator terhadap paket pembelajaran.

Instrumen yang digunakan dalam penelitian pengembangan ini berupa angket validasi paket pembelajaran untuk validator dan angket uji kelompok kecil oleh siswa. Instrumen pengumpulan data berisi skor 5, 4, 3, 2, 1 sesuai dengan skala Likert. Skor yang diperoleh dari instrumen pengumpulan data tersebut dikonversikan dalam bentuk nilai validitas dengan menggunakan rumus berikut. 


$$
P=\frac{\sum x}{n}
$$

Keterangan:

$\mathrm{P} \quad=$ skor kevalidan

$\Sigma x \quad=$ jumlah jawaban tiap responden dari tiap item yang dinilai

$\mathrm{n} \quad=$ jumlah responden

Tingkat kriteria validasi yang digunakan dalam penelitian pengembangan paket pembelajaran ini disajikan dalam tabel 3.1.

Tabel 1 Kriteria Validasi dari Tiap Item pada Angket

\begin{tabular}{lll}
\hline Skor & Kriteria Validasi & Keterangan \\
\hline $4,2 \leq P \leq 5,00$ & Sangat valid, sangat layak & Tidak perlu revisi \\
$3,4 \leq P \leq 4,1$ & valid, layak & Tidak perlu revisi \\
$2,6 \leq P \leq 3,3$ & Cukup valid, cukup layak & Tidak perlu revisi \\
$1,8 \leq P \leq 2,5$ & Tidak valid, tidak layak & Perlu revisi \\
$1 \leq P \leq 1,7$ & Sangat tidak valid, sangat tidak layak & Revisi total \\
\hline
\end{tabular}

(Sumber : Arikunto, 2002: 216)

\section{Hasil dan Pembahasan}

\subsection{Hasil Validasi Paket IPA Terpadu dan Panduan Penggunaannya}

Hasil penilaian paket pembelajaran beserta panduan pengunaannya dari para validator menunjukkan skor antara 3-5 dari skor maksimal 5. Perolehan skor dari validator ini dikonversikan ke dalam bentuk nilai validitas untuk mengetahui tingkat kevalidan paket pembelajaran dan panduan penggunaannya. Kevalidan tersebut diperoleh dari analisis per aspek yang dinilai dalam paket pembelajaran. Aspek yang dinilai dalam paket meliputi kesesuaian uraian materi dengan KI dan KD, keakuratan materi, materi pendukung pembelajaran, teknik penyajian, penyajian pembelajaran, dan kelengkapan penyajian. Aspek yang dinilai dalam panduan paket pembelajaran meliputi kelayakan isi dan kelayakan penyajian. Nilai dan kriteria per aspek dalam paket pembelajaran dapat dilihat pada tabel berikut.

Tabel 2 Data Hasil Validasi Paket IPA Terpadu (Buku Pegangan Siswa)

\begin{tabular}{llll}
\hline No. & Aspek yang dinilai & $\begin{array}{l}\text { Nilai yang } \\
\text { diperoleh }\end{array}$ & Kriteria \\
\hline 1 & Kesesuaian uraian materi dengan KI dan KD & 4.04 & Valid \\
2 & Keakuratan materi & 4.47 & Sangat Valid \\
3 & Materi pendukung pembelajaran & 4.78 & Sangat Valid \\
4 & Teknik penyajian & 4.5 & Sangat Valid \\
5 & Penyajian pembelajaran & 4 & Valid \\
6 & Kelengkapan penyajian & 4.28 & Sangat Valid \\
\hline & Rata-rata & 4.35 & Sangat Valid \\
\hline
\end{tabular}


Tabel 3 Data Hasil Validasi Panduan Paket IPA Terpadu (Buku Panduan Guru)

\begin{tabular}{llll}
\hline No. & Aspek yang dinilai & Nilai yang diperoleh & Kriteria \\
\hline 1 & Kelayakan isi & 4.63 & Sangat Valid \\
2 & Kelayakan penyajian & 3.89 & Valid \\
\hline & Rata-rata & 4.26 & Sangat Valid \\
\hline
\end{tabular}

Hasil analisis skor validasi per aspek dalam panduan paket pembelajaran didapatkan nilai kevalidan secara keseluruhan sebesar 4.35 untuk paket pembelajaran dan 4.26 untuk panduan penggunaannya. Hasil ini menunjukkan bahwa paket pembelajaran beserta panduan penggunaannya memenuhi kriteria sangat valid. Artinya paket pembelajaran yang dikembangkan sangat layak digunakan.

\subsection{Hasil Uji Coba Kelompok Kecil}

Revisi paket pembelajaran dilakukan berdasarkan saran yang diberikan oleh validator setelah proses validasi. Setelah melakukan revisi paket pembelajaran kemudian dilanjutkan dengan kegiatan uji coba kelompok kecil. Uji coba ini bertujuan untuk mengetahui keterbacaan paket pembelajaran yang telah dikembangkan. Uji keterbacaan dilaksanakan di SMP Negeri 2 Tumpang kelas VIII-B dengan jumlah siswa 12 orang.

Hasil penilaian paket pembelajaran dari siswa menunjukkan skor antara 3-5 dari skor maksimal 5. Perolehan skor dari siswa ini dikonversikan ke dalam bentuk nilai validitas untuk mengetahui tingkat kevalidan paket pembelajaran (buku pegangan siswa). Kevalidan tersebut diperoleh dari analisis per aspek yang dinilai dalam paket pembelajaran. Aspek yang dinilai dalam paket pembelajaran meliputi aspek penampilan, aspek penyajian materi, aspek manfaat. Nilai dan kriteria per aspek dalam panduan paket pembelajaran dapat dilihat pada tabel berikut.

Tabel 4 Hasil Uji Keterbacaan Paket IPA Terpadu

\begin{tabular}{llll}
\hline No. & Aspek yang dinilai & Nilai yang diperoleh & Kriteria \\
\hline 1 & Aspek Penampilan & 4.67 & Sangat Valid \\
2 & Aspek Penyajian Materi & 4.25 & Sangat Valid \\
3 & Aspek Manfaat & 4.03 & Valid \\
\hline & Rata-rata & 4.32 & Sangat Valid \\
\hline
\end{tabular}

Paket IPA terpadu ini dikembangkan dengan landasan model pembelajaran berbasis inkuiri. Tahapan pembelajaran inkuiri tercermin dalam paket pembelajaran yang berupa lembar kerja yang terintegrasi dengan materi dalam paket pembelajaran. Dampak instruksional yang diharapkan dapat muncul setelah siswa menggunakan paket pembelajaran ini sebagai sumber belajar yaitu meningkatkan pemahaman konsep siswa. Pemahaman konsep yang diharapkan yaitu siswa dapat memahami konsep yang dipelajari melalui percobaan dalam paket dan siswa dapat mengenal penerapan konsep yang telah dipelajari dalam kehidupan sehari-hari.

Berdasarkan hasil validasi dari kedua validator, paket IPA terpadu memperoleh nilai validitas sebesar 4.6 dengan kriteria sangat valid dalam aspek pendekatan 
berbasis inkuiri. Artinya paket tersebut sudah disusun memenuhi pendekatan berbasis inkuiri. Dampak yang ingin dimunculkan ketika siswa menggunakan paket IPA terpadu yang telah dikembangkan dengan pendekatan berbasis inkuiri adalah meningkatkan pemahaman konsep siswa. Untuk mengukur pemahaman konsep siswa, seharusnya penelitian dilakukan dengan uji empirik atau uji keterlaksanaan pembelajaran. Pada penelitian pengembangan ini hanya dilakukan sampai pada tahap uji keterbacaan, dikarenakan keterbatasan waktu, biaya, dan tenaga peneliti, sehingga aspek hubungan pembelajaran berbasis inkuiri mampu meningkatkan pemahaman konsep siswa setelah belajar menggunakan paket yang telah dikembangkan dapat diketahui dari penilaian oleh kedua validator. Hasil penilaian dari kedua validator menunjukkan bahwa aspek hubungan pembelajaran berbasis inkuiri mampu meningkatkan pemahaman konsep siswa memperoleh nilai validitas sebesar 4.75 dengan kriteria sangat valid. Artinya paket IPA terpadu ini sangat layak digunakan oleh siswa sebagai sumber belajar berbasis inkuiri yang mampu meningkatkan pemahaman konsep siswa setelah belajar menggunakan paket yang telah dikembangkan.

Salah satu karakteristik pembelajaran IPA SMP/MTs berdasarkan kurikulum 2013 yang berlaku saat ini adalah menggunakan pendekatan ilmiah yang dapat membantu siswa untuk mencapai kompetensi yang akan dicapainya. Pendekatan ilmiah ini didukung dengan penerapan pembelajaran berbasis discovery/inkuiri untuk mendorong kemampuan siswa supaya menghasilkan keterampilan dan pemahaman suatu konsep yang dipelajarinya (Permendikbud No.65 Tahun 2013). Hasil yang diharapkan dengan menggunakan pembelajaran tersebut siswa dapat memperoleh pemahaman yang utuh/holistik sesuai dengan prinsip pembelajaran IPA yang mencakup penguasaan tiga ranah yaitu pengetahuan, keterampilan, dan sikap.

Pembelajaran IPA di sekolah dengan menerapkan model inkuiri bertujuan agar siswa memiliki pengetahuan, gagasan, dan konsep yang terorganisasi tentang alam sekitar yang diperoleh dari pengalaman melalui proses ilmiah (Istiani, 2015). Pembelajaran yang dilakukan secara inkuiri lebih berpotensi untuk mengembangkan pengalaman dan kompetensi siswa untuk memahami alam sekitar sehingga siswa dapat menunjukkan adanya peningkatan aktifitas belajar yang meliputi kemampuan berpikir, sikap ilmiah, dan keterampilan proses (Listyawati, 2012; Khanifah, 2012). Pemahaman konsep siswa diperoleh dari seiring berjalannya kemampuan berpikir, sikap ilmiah, dan keterampilan proses siswa. Pembelajaran IPA yang dilakukan dengan model inkuiri dapat membantu siswa mengaplikasikan konsep yang dipelajarinya untuk memecahkan masalah dalam kehidupan sehari-hari. Menurut Jannah (2012) dengan penerapan pembelajaran berbasis inkuiri dapat meningkatkan kualitas pemahaman konsep siswa dan mampu tertanam karakter pada siswa. Lawson (2000) juga mengungkapkan bahwa pembelajaran berbasisi inkuiri dapat mengembangkan kemampuan berpikir kritis dan penguasaan konsep siswa.

Paket pembelajaran IPA terpadu berbasis inkuiri dengan tema cahaya dirancang agar siswa dapat membangun konsep berdasarkan fakta melalui pengamatan atau penyelidikan ilmiah. Paket pembelajaran ini menuntun siswa memperbaiki proses belajar untuk mendapatkan hasil belajar yang maksimal. Dalam paket pembelajaran ini untuk mengetahui kualitas pemahaman konsep melalui proses belajar ilmiah terdapat soal evaluasi . 
Paket pembelajaran berbasis inkuiri tema cahaya ini memiliki kelebihan dan kekurangan. Kelebihan dari paket pembelajaran ini adalah (1) tampilan yang menarik sehingga membantu siswa tidak mudah bosan untuk belajar IPA, (2) kegiatan-kegiatan belajar yang disajikan dalam paket pembelajaran dirancang agar siswa dapat membangun konsep berdasarkan hasil pengamatannya, sehingga konsep yang dipelajari tidak mudah hilang atau menjadi long term memory, (3) setiap konsep diawali dengan penyajian permasalahan yang timbul dari kehidupan sehari-hari siswa, dengan begitu siswa lebih mudah memahami permasalahan yang diberikan dan terlatih untuk memecahkannya, (4) penjelasan konsep disertai dengan contoh konkret yang ada dalam kehidupan sehari-hari siswa, (5) dilengkapi dengan panduan guru yang bertujuan untuk mempermudah guru dalam membimbing siswa dalam melaksanakan pembelajaran menggunakan paket yang telah dikembangkan.

Kelemahan dari paket pembelajaran ini adalah (1) pengembangan paket pembelajaran ini belum diterapkan dalam pembelajaran secara menyeluruh sehingga tidak dapat diketahui keefektifan dari paket yang dikembangkan, (2) terbatas pada materi yang terkait dengan tema cahaya, (3) hanya dilakukan uji keterbacaan sehingga belum diketahui efektifitas penggunaan paket pembelajaran ini dibandingkan yang tidak belajar dengan paket pembelajaran IPA terpadu.

\section{Simpulan}

\subsection{Kesimpulan}

Kesimpulan dari penelitian dan pengembangan ini yaitu: (1) paket IPA terpadu yang dikembangkan terdiri dari buku pegangan siswa dan buku panduan guru, (2) hasil validasi paket IPA terpadu memperoleh nilai validitas sebesar 4.35 dengan kriteria sangat valid, (3) hasil validasi panduan paket IPA terpadu memperoleh nilai validitas sebesar 4.26 dengan kriteria sangat valid, (4) hasil uji keterbacaan terhadap paket IPA terpadu memperoleh nilai validitas sebesar 4.32 dengan kriteria sangat valid, sehingga paket IPA terpadu yang dikembangkan layak digunakan.

\subsection{Saran}

Saran pengembangan produk yaitu: (1) perlu diuji coba lebih lanjut karena pada penelitian pengembangan ini hanya sampai uji keterbacaan saja, (2) aplikasi paket pembelajaran ke dalam pembelajaran bertujuan untuk menguji efektivitasnya dalam membantu proses belajar, (3) dalam rangka memperkaya dan meningkatkan kualitas pendidikan, perlu adanya penelitian dan pengembangan paket pembelajaran pada materi-materi selain materi cahaya.

\section{Daftar Rujukan}

Aisya, N., Wibowo, Y. \& Aminatu, T. (2014). Pengaruh Pembelajaran Socio Scientific Issues Terhadap Pemahaman Konsep dan Reflective Judgment Siswa SMA pada Materi Ekosistem. Jurnal Pendidikan Matematika dan Sains, 1 (1): 1-11

Anggareni, N. W., Ristiati, N. P., \& Widiyanti, N. L. P. M. (2013). Implementasi strategi pembelajaran inkuiri terhadap kemampuan berpikir kritis dan pemahaman konsep IPA siswa SMP. Jurnal Pendidikan dan Pembelajaran IPA Indonesia, 3(1).

Arikunto, S. (2002). Prosedur Penelitian Suatu Pendekatan Prakte., jakarta: PT Rineka Cipta. 
Arikunto, S. (2006). Prosedur Penelitian Suatu Praktek: Edisi Revisi IV. Jakarta: Pendekatan PT. RINEKA CIPTA, Jakarta.

Astuti, Y., \& Setiawan, B. (2013). Pengembangan lembar kerja siswa (LKS) berbasis pendekatan inkuiri terbimbing dalam pembelajaran kooperatif pada materi kalor. Jurnal Pendidikan IPA Indonesia, 2(1).

Bachtiar, H. (2010). Pengembangan Paket IPA Terpadu Berbasis Konstruktivisme dengan Tema Pemanasan Global bagi Siswa Kelas IX di SMP Negeri 2 Singosari. Skripsi (Tidak Diterbitkan). Pendidikan Fisika, Universitas Negeri Malang : Malang

Balım, A. G. (2009). The Effects of Discovery Learning on Students' Success and Inquiry Learning Skills. Eurasian Journal of Educational Research (EJER), (35).

Branch, R. M. (2009). Instructional design: The ADDIE approach (Vol. 722). Springer Science \& Business Media.

Istiani, R. M., \& Retnoningsih, A. (2015). Pemanfaatan lingkungan sekolah sebagai sumber belajar menggunakan metode post to post pada materi klasifikasi makhluk hidup. Journal of Biology Education, 4(1).

Jannah, M. (2012). Pengembangan perangkat pembelajaran berorientasi nilai karakter melalui inkuiri terbimbing materi cahaya pada siswa kelas VIII sekolah menengah pertama. Journal of Innovative Science Education, 1(1).

Khanifah, S., Pukan, K. K., \& Sukaesih, S. (2012). Pemanfaatan lingkungan sekolah sebagai sumber belajar untuk meningkatkan hasil belajar siswa. Journal of Biology Education, 1(1).

Koes H, S. (2006). Kajian Pelaksanaan Pembelajaran IPA Terpadu di SMP Jawa Timur. Jurnal Foton Vol 10 No 2 Agustus 2006.

Koes H, S. (2010). Pengembangan Paket IPA Terpadu Berbasis Kontruktivisme Untuk Menumbuhkan Kompetensi IPA. Laporan Penelitian tidak diterbitkan. Malang: FMIPA UM.

Kurniawan, A. D. (2013). Metode inkuiri terbimbing dalam pembuatan media pembelajaran biologi untuk meningkatkan pemahaman konsep dan kreativitas siswa SMP. Jurnal Pendidikan IPA Indonesia, 2(1).

Kusumawardhany, S. (2012). Pengaruh Pendekatan Salingtemas Pada Proses Pembelajaran Pencemaran Lingkungan terhadap Sikap Positif dan Penguasaan Konsep Siswa Kelas VII. E Jurnal Jurusan Pendidikan Biologi FMIPA UNY, (Online), (http:/journal.uny.ac.id/sju/index.php), diakses 8 Juni 2016.

Lane, J. L. (2007). Inquiry Based Learning. Penn State: Schreyer Institute for Teaching Excellence, University Park. (Online), (www.schreyerinstitute.psu.edu), diakses 1 Juni 2016.

Lawson, A. E. (2000). Managing the inquiry classroom: problems \& solutions. The American Biology Teacher, 62(9), 641-648.

Listyawati, M. (2012). Pengembangan Perangkat Pembelajaran IPA Terpadu SMP. Unnes Journal of Innovative Science Education. (Online). 1 (1): 61-69

Novana, T. (2014). Pengembangan modul inkuiri terbimbing berbasis potensi lokal pada materi tumbuhan lumut (Bryophyta) dan tumbuhan paku (Pteridophyta) (Doctoral dissertation, UNS (Sebelas Maret University)).

Novitaningrum, M., Parmin, P., \& Pamelasari, S. D. (2014). Pengembangan Handout Ipa Terpadu Berbasis Inkuiri Pada Tema Mata Untuk Kelas IX Siswa MTS Al-Islam Sumurejo. Unnes Science Education Journal, 3(2).

Penyusun, T. (2013). Permendikbud No. 65 tahun 2013 tentang Standar Proses Pendidikan Dasar dan Menengah. Jakarta: Kemdikbud.

Poerwati, E. L dan Amri, S. (2013). Panduan Kurikulum 2013. Jakarta: PT. Prestasi Pustakaraya.

Prayitno, B. A. (2011). Pengembangan Perangkat Pembelajaran IPA Biologi SMP Berbasis Inkuiri Terbimbing dipadu Kooperatif STAD serta Pengaruhnya terhadap Kemampuan Berpikir Tingkat Tinggi, Metakognisi, dan Keterampilan Proses Sains.(Disertasi). DISERTASI dan TESIS Program Pascasarjana UM.

Sugiyono. (2013). Metode Penelitian Pendidikan. Bandung: Alfabeta.

Trian, E. A., Haryani, S., \& Sedyawati, S. M. R. (2013). Pengembangan Modul IPA Terpadu Berkarakter pada Tema Pengelolaan Lingkungan untuk Kelas VII SMP. Unnes Science Education Journal, 2(2). 
Utami, F. N., Ridlo, S., \& Widiyatmoko, A. (2014). Pengembangan Lks Ipa Terpadu Berbasis Permainan Edukatif Tema Tekanan Dalam Sistem Peredaran Darah Manusia Untuk Siswa Kelas VIII. Unnes Science Education Journal, 3(3).

Wisudawati, A. W. \& Sulistyowati, E. (2015). Metodologi pembelajaran IPA. Jakarta: PT Bumi Aksara. 